\title{
FORMULATION AND EVALUATION OF MATRIX DIFFUSION CONTROLLED TRANSDERMAL DRUG DELIVERY SYSTEM OF GLIPIZIDE
}

\author{
Patel Chirag J*, Mangukia Dhruv K, Asija Rajesh, Asija Sanjeeta, Kataria Sandeep, Patel Pinkesh \\ Maharishi Arvind Institute of Pharmacy, Mansarovar, Jaipur-302020, India \\ *Corresponding Author’s E-mail: chirag.bangalore@gmail.com
}

Received 22 Nov 2011; Revised 26 Dec 2011; Accepted 08 Jan 2012, Available online 20 Jan 2012

\begin{abstract}
:
There has been a tremendous increase in interest for transdermal drug delivery system for sustain release dosage form in chronic manageable diseased conditions like diabetes, hypertension etc to reduce the frequency of dosing. It reduces the risk of exposing the body to drug above maximum safe concentration in case of dosage form failure in comparison to oral sustained release drug delivery system. It also reduces the frequency of dosing and improves patient compliance. Transdermal patches of Glipizide were formulated to achieve sustain release pattern within the therapeutic range. HPMC 5cps, HPMC 15cps, HPMC K-100M, Ethyl cellulose (EC), Eudragit RS 100 (ERS-100) and Polyvinylpyrrolidone (PVP) K30 were used as matrix forming polymer. Propylene glycol was used as penetration enhancer. Polyethylene glycol (PEG) 400 and n-dibultyl phthalate (n-DB) were used as plasticizer. Methanol and chloroform were used as solvents. Patches were prepared by solvent casting method. Prepared patches were evaluated for physicochemical parameters like weight variation, thickness, folding endurance, drug content, \% moisture absorption and \% elongation break test. Patches prepared, from each batch, gave release profile for over 10 hours. Cumulative amount of drug release in 12 hours from all the prepared formulations were found to be in following order: F1 $>$ F3 $>$ F4 $>$ F10 $>$ F9 $>$ F6 $>$ F8 $>$ F7 $>$ F2 $>$ F5 $>$ F11 $>$ F12. Prepared patch from HPMC 5 cps and ethyl cellulose (F1) exhibited good characteristics for sustained release action and other parameters evaluated.
\end{abstract}

Key-words: sustained release patches, Glipizide, transdermal patches, diabetes.

\section{INTRODUCTION:}

Diabetes mellitus is a chronic metabolic disorder characterised by high blood glucose level due to insulin deficiency. It is a major and still growing health problem worldwide. Glipizide is a second generation sulfonylurea used as oral hypoglycaemic agent. Glipizide (sulfonylureas) provoke release of insulin from pancreas by acting on sulfonylurea receptors on the pancreatic $B$ cell membrane. Transdermal patches of glipizide offer an advantage of reduced dosing frequency, thus enhancing patient compliance. Drug delivery through skin bypasses hepatic first pass metabolism which cannot be bypassed in oral route. Glipizide is used in NIDDM and acts by increasing the release of endogeneous insulin and its peripheral effectiveness. ${ }^{12}$. The present study was aimed at development of matrix diffusion controlled transdermal patches using different polymers and different penetration enhancers. Literature survey revealed that use of HPMC $5 \mathrm{cps}^{17,18}, \mathrm{EC}^{17}$ and PVP K $30^{18}$ as polymers forms matrix patches and gives release for more than 10 hours. Literature survey also revealed that use of PEG 400 as plasticizer produced films with high folding ndurance. ${ }^{18}$

\section{MATERIALS AND METHODS:}

\section{Materials:}

Glipizide was received as a gift sample from Ronak Pharmaceuticals pvt Ltd., Patan. Eudragit RS 100 was received as a gift sample form Roehm Pharma polymers. HPMC 5 cps, HPMC 15 cps, PVP K 30, HPMC K 100M, Ethyl cellulose, Propylene glycol, PEG 400, n-dibutyl phthalate, Methanol and Chloroform were purchased from Central Drug House (P) Ltd., New Delhi.

\section{Method: ${ }^{7,11}$}

Preparation of patches: Matrix type transdermal patches loaded with Glipizide were prepared by solvent casting method. Required quantities of polymers were weighed and dissolved in $10 \mathrm{ml}$ mixture of methanol and chloroform in the ratio $1: 1$. Sonicate for $30 \mathrm{~min}$. Stir for 1 hour on a magnetic stirrer at 400rpm. $73.88 \mathrm{mg}$ of drug was weighed and added to the above solution. Required quantity of PEG 400, n-DB (as plasticizers) and propylene glycol (as penetration enhancer) were measured and added to the above solution. Stir on a magnetic stirrer at $400 \mathrm{rpm}$ for 2 hours. The resulted uniform solution was cast on a Petri dish of area $66.50 \mathrm{~cm}^{2}$, previously containing a layer of mercury. An inverted funnel was placed over the Petri dish to prevent the fast evaporation of the solvent. After 24 hours, the dried patches were taken out, cut into pieces of $3 \mathrm{~cm} * 3 \mathrm{~cm}$ (area $=9 \mathrm{~cm}^{2}$ and containing $10 \mathrm{mg}$ of the Glipizide) and stored in a desiccator.

\section{EVALUATION: ${ }^{1,2,7,11}$}

1. Weight uniformity:

The prepared patches are to be dried at $60^{\circ} \mathrm{C}$ for 4 hours before testing. Weight uniformity was done by weighing 5 different patches of each batch. All the patches, selected at random, should be uniform in size $(3 \mathrm{~cm} * 3 \mathrm{~cm})$. Calculate the average weight of three. 
Table 1: Formulation for Glipizide transdermal patches

\begin{tabular}{|c|c|c|l|c|c|c|l|l|l|}
\hline \multirow{2}{*}{$\begin{array}{c}\text { BATCH } \\
\text { CODE }\end{array}$} & $\begin{array}{l}\text { HPMC } \\
\mathbf{5} \mathbf{c p s} \\
(\mathbf{m g})\end{array}$ & $\begin{array}{l}\text { HPMC 15 } \\
\mathbf{c p s} \\
(\mathbf{m g})\end{array}$ & $\begin{array}{l}\text { HPMC K 100M } \\
(\mathbf{m g})\end{array}$ & $\begin{array}{l}\text { EC } \\
(\mathbf{m g})\end{array}$ & $\begin{array}{l}\text { PVP K30 } \\
(\mathbf{m g})\end{array}$ & $\begin{array}{l}\text { ERS } \\
\mathbf{1 0 0} \\
(\mathbf{m g})\end{array}$ & $\begin{array}{l}\text { PG } \\
(\mathbf{m g})\end{array}$ & $\begin{array}{l}\text { PEG } \\
\mathbf{4 0 0} \\
(\mathbf{m l})\end{array}$ & $\begin{array}{l}\text { n-DB } \\
(\mathbf{m l})\end{array}$ \\
\hline F1 & 460 & - & - & 840 & - & - & 208 & 0.3 & 0.3 \\
\hline F2 & 1070 & - & - & - & 230 & - & 208 & 0.3 & 0.3 \\
\hline F3 & 650 & - & - & 650 & - & - & 208 & 0.3 & 0.3 \\
\hline F4 & 500 & - & - & 800 & - & - & 208 & 0.6 & - \\
\hline F5 & 980 & - & - & - & 320 & - & 208 & - & 0.6 \\
\hline F6 & - & 460 & - & 840 & - & - & 208 & 0.2 & 0.4 \\
\hline F7 & - & 650 & - & 650 & - & - & 208 & 0.4 & 0.2 \\
\hline F8 & - & 500 & - & 800 & - & - & 208 & 0.1 & 0.5 \\
\hline F9 & 460 & - & - & - & - & 840 & 208 & 0.26 & 0.26 \\
\hline F10 & 650 & - & - & - & - & 650 & 208 & 0.26 & 0.26 \\
\hline F11 & - & - & 650 & 650 & - & - & 208 & 0.3 & 0.3 \\
\hline F12 & - & - & 450 & 850 & - & - & 208 & 0.2 & 0.4 \\
\hline
\end{tabular}

2. Thickness of the patch:

The thickness of the patch is measured by digital micrometer at different points. For each formulation, three patches were used. The average value for the thickness of single patch was determined.

3. Folding endurance:

A strip of specific area $(3 \mathrm{~cm} * 3 \mathrm{~cm})$ is to be cut evenly and repeatedly folded at the same place till it broke. The number of times the film could be folded without breaking gave the value of folding endurance.

4. Percentage moisture content:

Three patches of the same composition were weighed and kept on desiccators containing fused calcium chloride at $37^{\circ} \mathrm{C}$ until no change in weight of the individual patches was observed. This weight was noted as the final weight. The percentage moisture content was calculated as a difference between individual and final weight. An average is shown in table-2.

5. Moisture uptake:

To determine the moisture uptake of the patches, three weighed patches of the same batch (kept in desiccator at $37^{\circ} \mathrm{C}$ until constant weight) were exposed to two different relative humidity conditions: $75 \% \mathrm{RH}$ (saturated solution of sodium chloride) and 93\% RH (saturated solution of ammonium hydrogen phosphate) respectively at room temperature. After 24 hours, the films were reweighed and percentage moisture uptake was determined from the below mentioned formula:

$$
\% \text { moisture content }=\frac{\text { initial weight }- \text { final weight }}{\text { final weight }} * 100
$$

6. Percentage elongation break test:

Percentage elongation is determined by measuring the length just before the breaking point. The percentage elongation can be determined from the below mentioned formula:

$$
\% \text { elongation }=\frac{\mathrm{L} 1-\mathrm{L} 2}{\mathrm{~L} 2} * 100
$$

Where;

$\mathrm{L} 1=$ final length of each strip.

L2 = initial length of each strip.

7. Drug content:

The film of $2 \mathrm{~cm}^{2}$ was cut into small pieces and taken into $100 \mathrm{ml}$ volumetric flask containing $20 \mathrm{ml}$ methanol. This methanolic solution was diluted with phosphate buffer $\mathrm{pH} 7.4$ up to $100 \mathrm{ml}$. the solution was filtered through whatmann filter paper and the drug content was determined on UV spectrophotometer at $\lambda_{\max } 275 \mathrm{~nm}$ after suitable dilutions.

8. In-vitro drug release studies:

The in-vitro drug release studies were carried out in a Franz diffusion cell. The cellulose acetate membrane (pore size $=0.45 \mu \mathrm{m}$ ) was mounted between donor and the receptor compartment of the diffusion cell. The transdermal film was placed on the cellulose acetate membrane and covered with aluminum foil. The receptor compartment was filled with freshly prepared phosphate buffer $\mathrm{pH} 7.4$ $(55 \mathrm{ml})$. The whole assembly was fixed on a magnetic stirrer with hot plate apparatus. The solution in receptor compartment was stirred at $35-45 \mathrm{rpm}$ and temperature was maintained at $32 \pm 0.5^{\circ} \mathrm{C}$. Sample $(3 \mathrm{ml})$ was withdrawn at different interval and replaced with the same volume of the phosphate buffer pH7.4. Samples were analyzed spectrophotometrically at $275 \mathrm{~nm}$.

9. Skin irritation study for F1:

Skin irritation testing can be performed on the healthy Albino rabbits weighing between 1.2-2.5 kg. Remove the hair from the dorsal surface and clean the dorsal surface using rectified spirit. Aqueous solution of formalin $0.8 \%$ was used as a standard irritant. Prepared transdermal patches of area $15 \mathrm{~cm}^{2}$ were used as test patches. $0.8 \%$ of formalin solution was applied in the right dorsal surface of each rabbits whereas test patches were applied on the left dorsal surface. The patches were removed after 24 hours and skin was examined. 
Table 2: Physicochemical evaluation parameters

\begin{tabular}{|c|c|c|c|c|c|}
\hline \multirow{2}{*}{$\begin{array}{c}\text { Batch } \\
\text { Code }\end{array}$} & $\begin{array}{c}\text { Weight Variation } \\
\text { (Mean (mg) } \pm \text { SD) }\end{array}$ & $\begin{array}{c}\text { Thickness } \\
\text { (Mean (mm) } \pm \text { SD) }\end{array}$ & $\begin{array}{c}\text { Moisture CONTENT } \\
\text { (Weight \%) }\end{array}$ & \multicolumn{2}{c|}{ Water Absorption (Weight \%) } \\
\cline { 2 - 6 } & & & & $75 \%$ RH & $93 \%$ RH \\
\hline F1 & $365 \pm 2.06$ & $0.15 \pm 0.021$ & 1.12 & 1.79 & 2.09 \\
\hline F2 & $364 \pm 4.02$ & $0.14 \pm 0.029$ & 1.13 & 1.81 & 2.32 \\
\hline F3 & $358 \pm 3012$ & $0.20 \pm 0.031$ & 1.18 & 2.02 & 2.82 \\
\hline F4 & $354 \pm 3.41$ & $0.17 \pm 0.020$ & 1.14 & 3.55 & 2.73 \\
\hline F5 & $357 \pm 5.11$ & $0.15 \pm 0.015$ & 1.18 & 3.52 & 3.45 \\
\hline F6 & $359 \pm 3.91$ & $0.19 \pm 0.018$ & 1.23 & 1.92 & 2.18 \\
\hline F7 & $351 \pm 2.98$ & $0.16 \pm 0.040$ & 1.14 & 3.30 & 3.64 \\
\hline F8 & $361 \pm 5.03$ & $0.18 \pm 0.025$ & 1.18 & 3.39 & 3.65 \\
\hline F9 & $367 \pm 4.08$ & $0.15 \pm 0.013$ & 1.19 & 3.68 & 3.71 \\
\hline F10 & $362 \pm 5.09$ & $0.19 \pm 0.025$ & 1.20 & 3.79 & 3.89 \\
\hline F11 & $342 \pm 3.58$ & $0.20 \pm 0.023$ & 1.23 & & 3.97 \\
\hline F12 & $341 \pm 3.59$ & $0.18 \pm 0.019$ & 1.25 & 3.78 \\
\hline
\end{tabular}

Table 3: Evaluation parameters

\begin{tabular}{|c|c|c|c|c|}
\hline \multirow{2}{*}{$\begin{array}{c}\text { BATCH } \\
\text { CODES }\end{array}$} & \multicolumn{4}{|c|}{ PARAMETERS } \\
ENDURING & $\begin{array}{c}\text { \% Elongation break } \\
\text { test }\end{array}$ & \% drug content & $\begin{array}{c}\text { cumulative drug } \\
\text { release }\end{array}$ \\
\hline F1 & $210 \pm 5.2$ & $40.2 \pm 0.012$ & $99.38 \pm 4.02$ & $55.87 \pm 0.009$ \\
\hline F2 & $212 \pm 3.2$ & $41.8 \pm 0.014$ & $97.02 \pm 3.32$ & $40.37 \pm 0.010$ \\
\hline F3 & $200 \pm 7.3$ & $39.7 \pm 0.012$ & $99.02 \pm 5.22$ & $51.14 \pm 0.044$ \\
\hline F4 & $198 \pm 3.9$ & $35.8 \pm 0.016$ & $96.91 \pm 4.13$ & $49.38 \pm 0.097$ \\
\hline F5 & $215 \pm 5.5$ & $41.9 \pm 0.011$ & $98.83 \pm 5.91$ & $38.31 \pm 0.021$ \\
\hline F6 & $210 \pm 7.6$ & $36.2 \pm 0.017$ & $96.79 \pm 3.51$ & $45.16 \pm 0.014$ \\
\hline F7 & $204 \pm 7.1$ & $32.1 \pm 0.13$ & $97.18 \pm 2.99$ & $42.58 \pm 0.029$ \\
\hline F8 & $211 \pm 3.8$ & $31.3 \pm 0.15$ & $98.23 \pm 3.12$ & $43.31 \pm 0.032$ \\
\hline F9 & $217 \pm 4.1$ & $42.1 \pm 0.11$ & $99.17 \pm 4.72$ & $45.31 \pm 0.029$ \\
\hline F10 & $214 \pm 7.7$ & $40.3 \pm 0.19$ & $99.03 \pm 4.18$ & $46.43 \pm 0.078$ \\
\hline F11 & $208 \pm 4.3$ & $33.2 \pm 0.13$ & $98.02 \pm 5.02$ & $31.46 \pm 0.096$ \\
\hline F12 & $212 \pm 5.3$ & $34.09 \pm 0.14$ & $98.09 \pm 6.01$ & $30.59 \pm 0.057$ \\
\hline
\end{tabular}

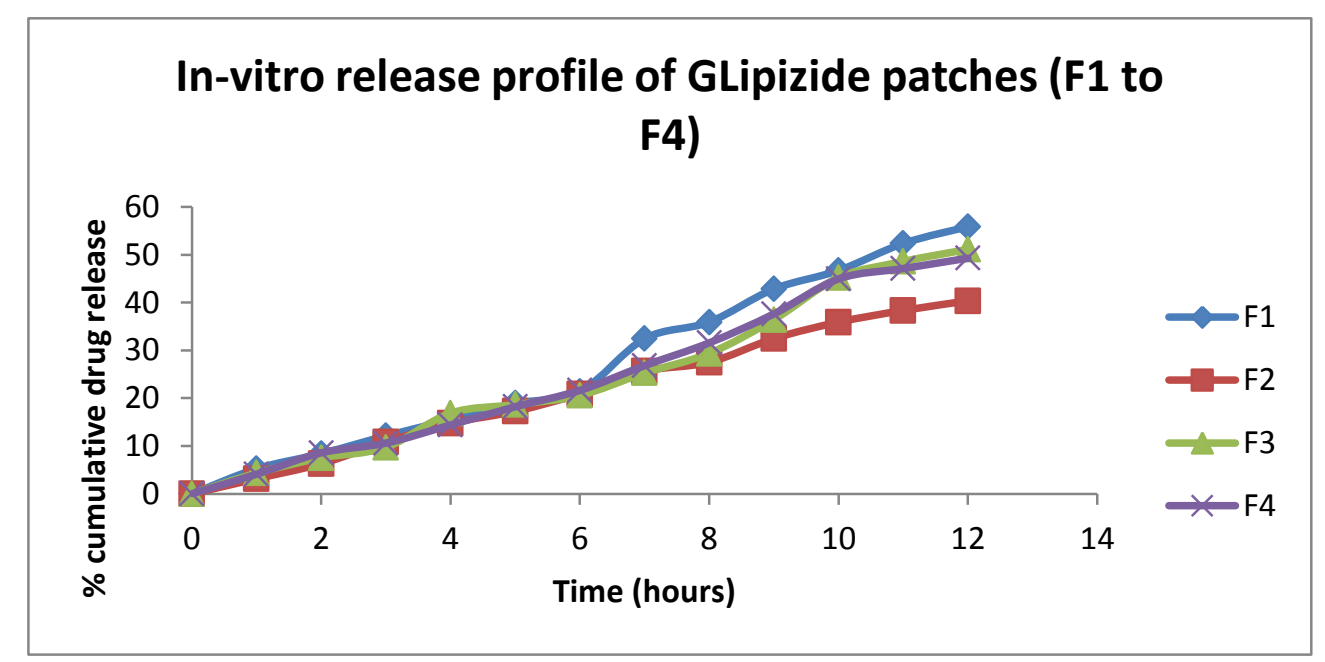

Figure 1: In vitro release profile of Glipizide patches (F1 to F4): 


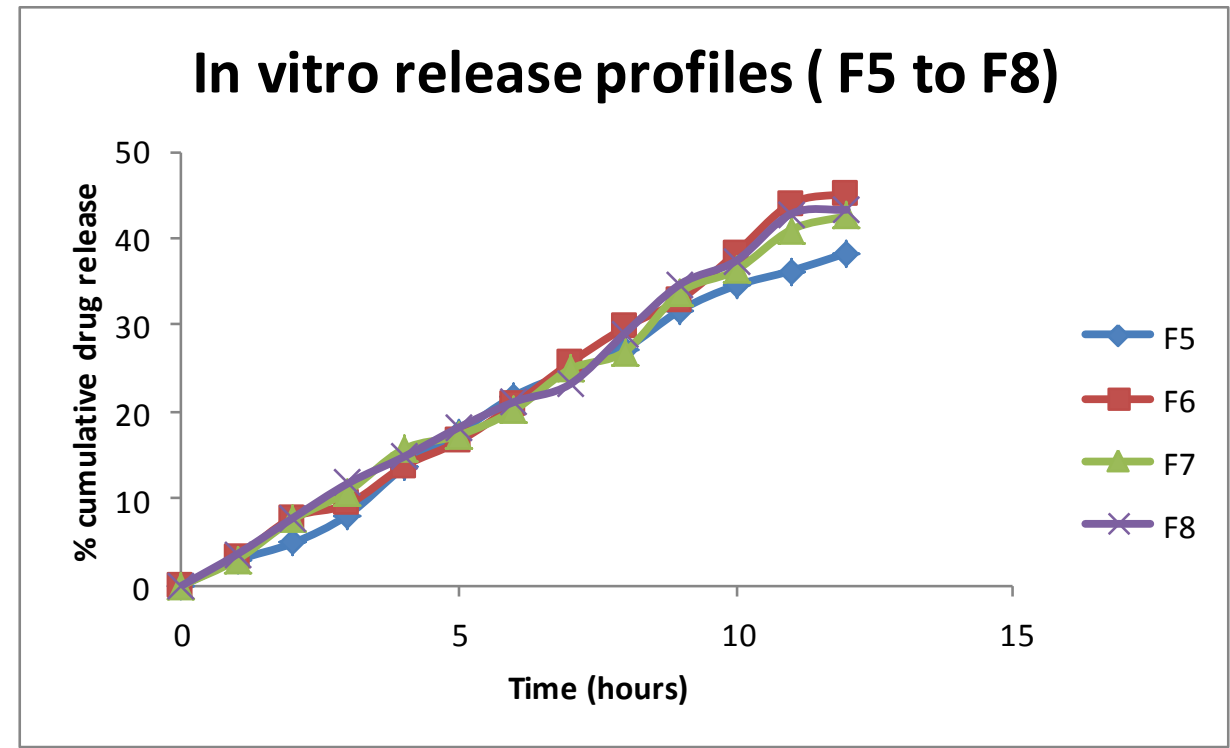

Figure 2: in vitro release profiles (F5 to F8)

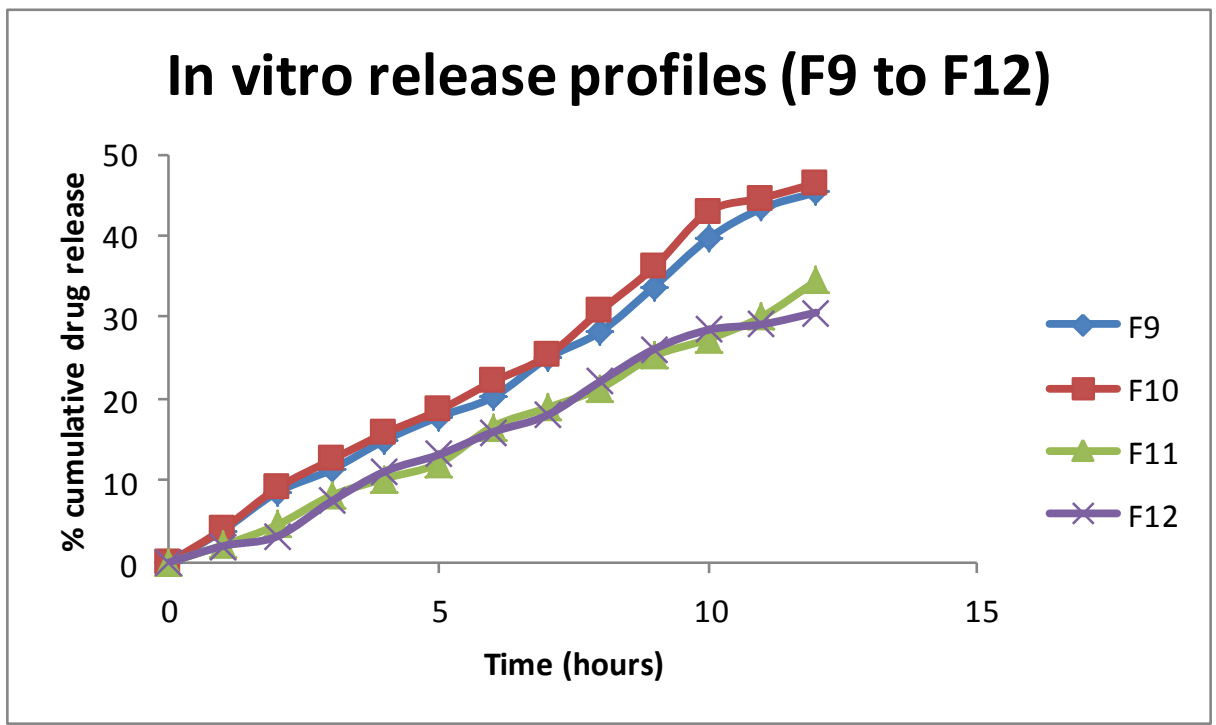

Figure 3: In vitro release profiles (F9 to F12)

\section{RESULTS AND DISCUSSION:}

Transdermal patches of Glipizide were prepared by solvent evaporation method in a Petri-dish on a mercury platform with an inverted funnel to control the rate of evaporation of the solvent. Different formulation (as shown in table 1) containing Glipizide were prepared to achieve the sustain release pattern within the therapeutic range.

\subsection{Investigation of drug-polymer compatibility:}

Drug - polymer compatibility was checked by comparing the IR spectra of formulations with that of the pure drug. No significant changes in the functional groups between the two spectra were observed. This ensured the compatibility of polymer with that of the drug.

\subsection{Transparency:}

Patches prepared from HPMC-PVP had maximum transparency, followed by HPMC-EC and HPMC -ERS.

\subsection{Physicochemical evaluation of transdermal patches:}

The results of the physicochemical evaluation of the transdermal patches are described in table 2 and table 3 . The weight variation of all the formulations varied in between $351 \pm 2.98$ and $365 \pm 2.06$. The variation in the thickness of all the formulation was in the range $0.14 \pm$ 0.029 to $0.20 \pm 0.031$. Moisture content of these patches was found to vary from 1.12 to 1.25 . Water absorption at $75 \% \mathrm{RH}$ and $93 \% \mathrm{RH}$ was observed from 1.79 to 3.78 and 2.09 to 3.97 respectively. This difference in the moisture content and water absorption was may be due to the difference in hydrophilicity of the polymers and extent of solvent evaporation during formulation. Folding endurance was found to be in between $180 \pm 7.7$ and $217 \pm 4.1$. The $\%$ elongation break test was found to be from $31.3 \pm 0.15$ to $42.1 \pm 0.11$. Folding endurance and $\%$ elongation break test was found maximum in formulation containing Eudragit RS 100 and PVP K 30 as polymers. The \% drug content and $\%$ cumulative drug release was found maximum in formulation F1 (batch code). 


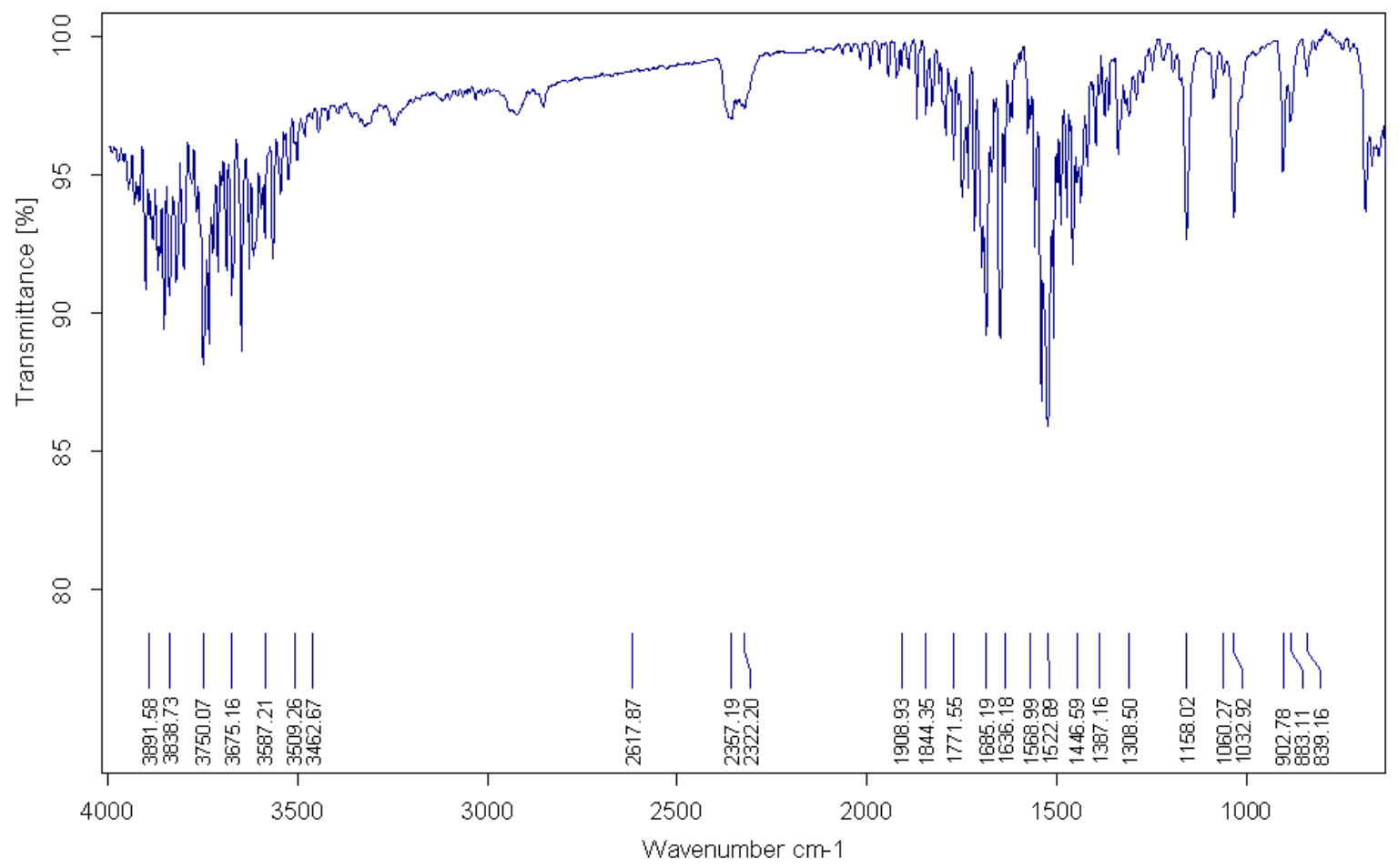

\begin{tabular}{|lc|c|}
\hline C:IProgram FilesłoPUS_65MMEASIGLIPIZIDE.0 & GLIPIZIDE $\quad$ ATR eco ZnSe & $13 / 10 / 2011$ \\
\hline
\end{tabular}

Page 1/1

Figure 4: IR spectra of Glipizide

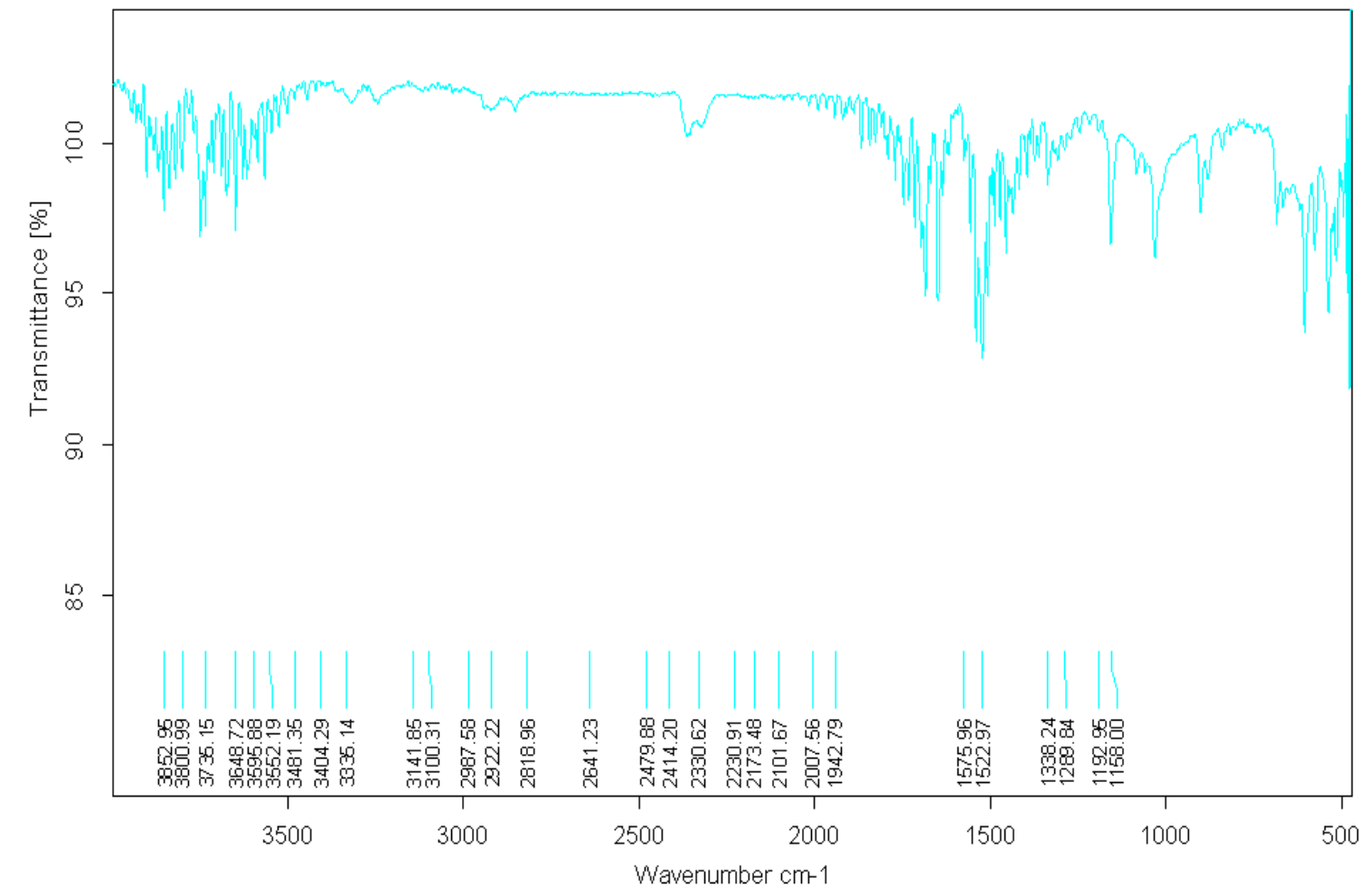

C:XProgram FilesioPUS_65MEASYHPMC 5-CPS \& EC \& GLIPIZIDE.0 HPMC 5-CPS \& EC \& GLIPIZIDE ATR eco ZnSe

Page 1/1

Figure 5: IR spectra of mixture of Glipizide, HPMC 5 cps and Ethyl cellulose 


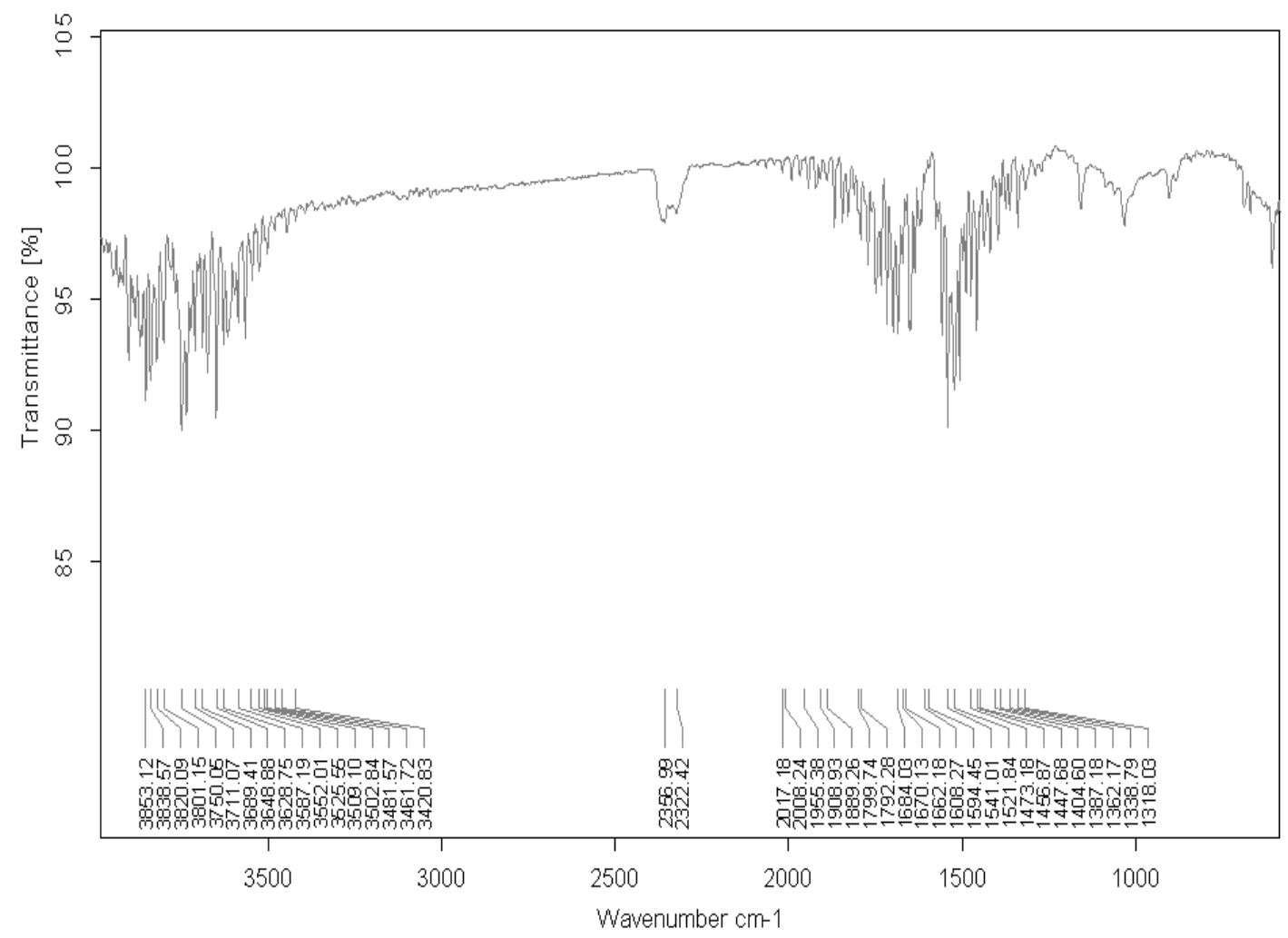

C:AProgram FilesiOPUS_65MMEASHPMC 5 cPs \& PVP K30 \& GLIPIZIDE.0 HPMC 5 cps \& PVP K30 \& GLIPIZIDE $\quad$ ATR eco ZnSe $\quad$ 13/10/2011

Page $1 / 1$

Figure 6: IR spectra of mixture of Glipizide, HPMC 5 cps and PVP K 30

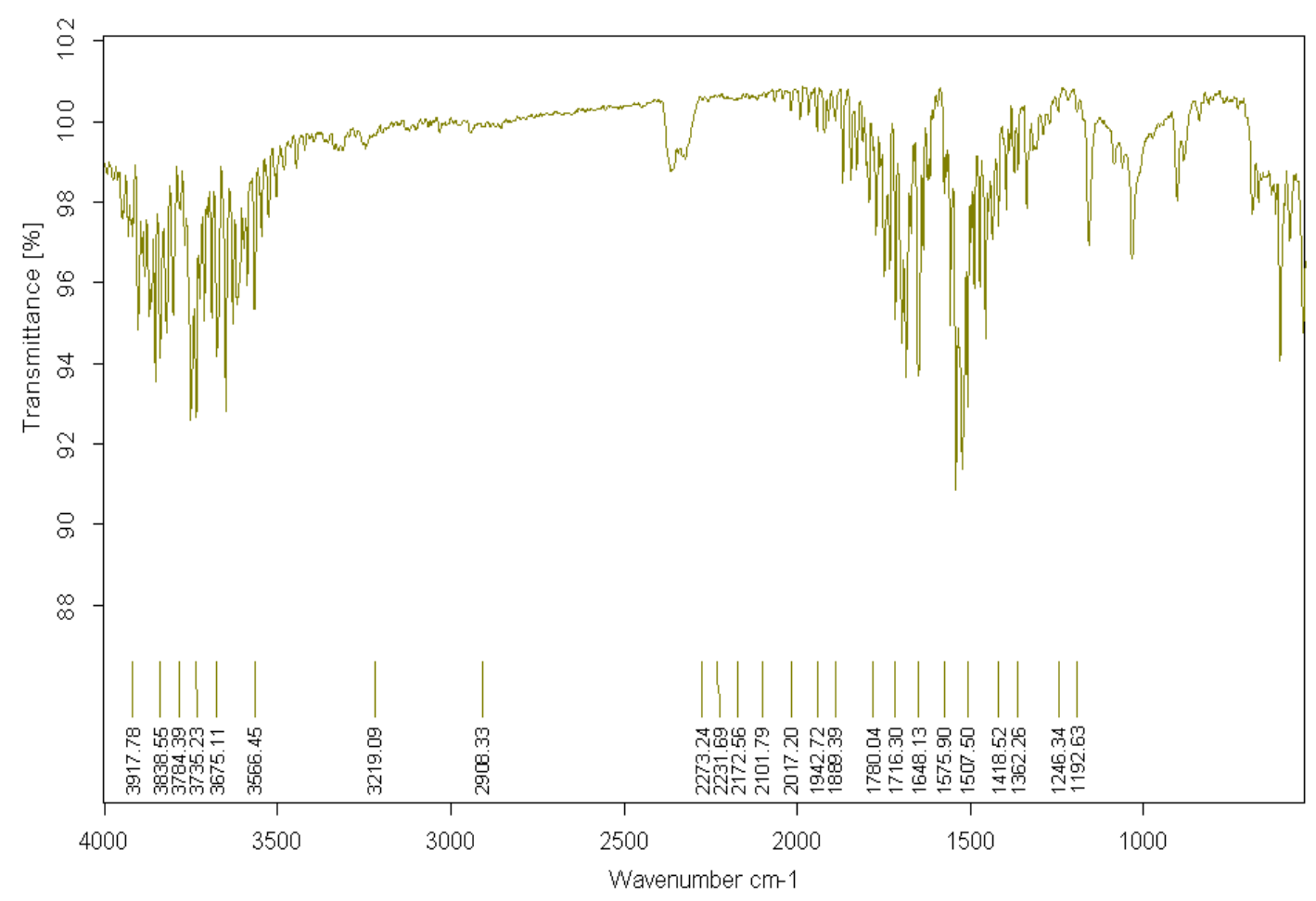

\begin{tabular}{|lll|l}
\hline C:Program FilesioPUS_65MEASTHPMC K100 \& EC \& GLIPIZIDE.0 $\quad$ HPMC K100 \& EC \& GLIPIZIDE $\quad$ ATR eco ZnSe & $13 / 10 / 2011$ \\
\hline
\end{tabular}

Page $1 / 1$

Figure 7: IR spectra of mixture of Glipizide, HPMC K 100 and Ethyl cellulose 

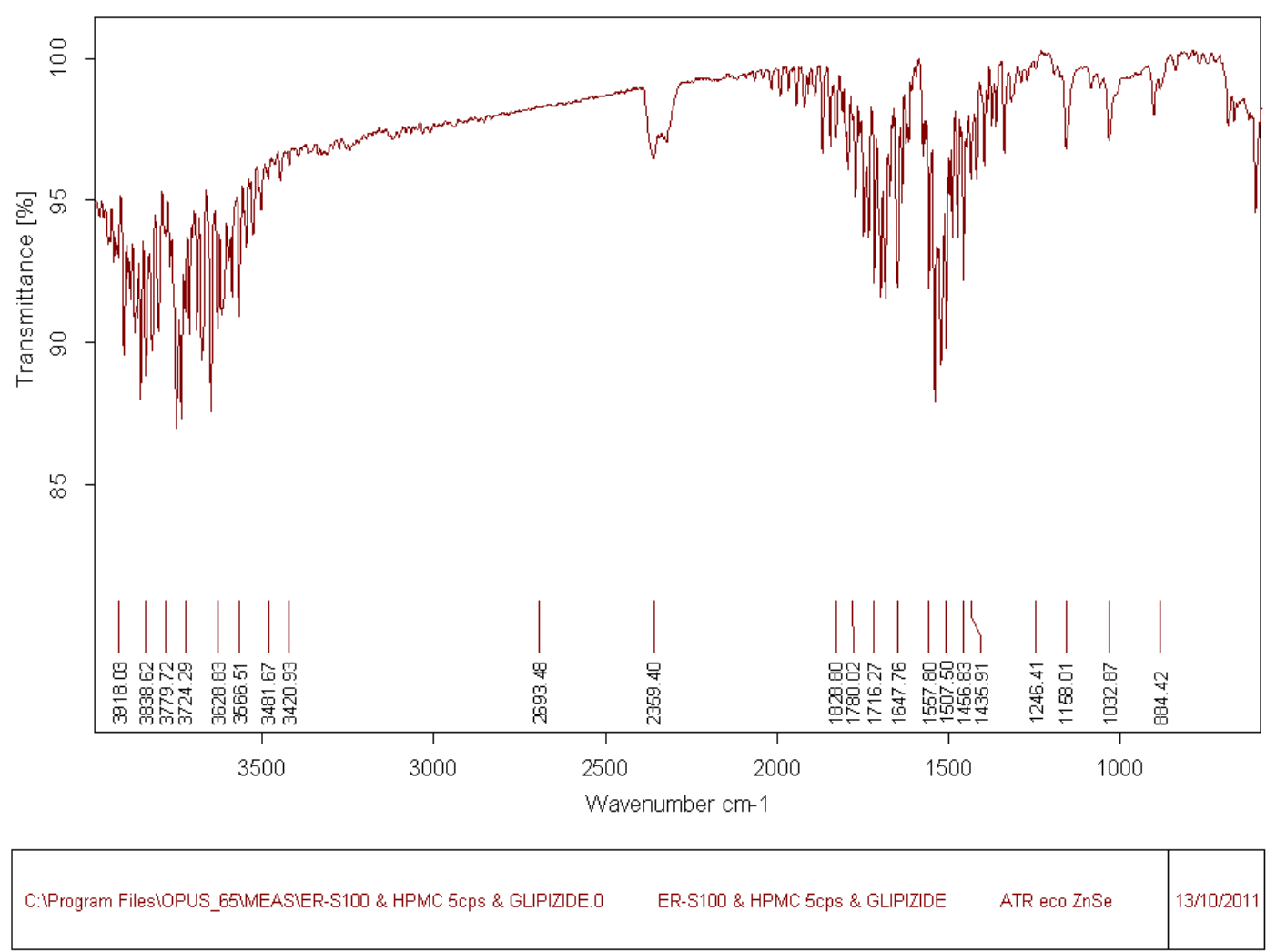

Page $1 / 1$

Figure 8: IR spectra of mixture of Glipizide, HPMC $5 \mathrm{cps}$ and Eudragit RS 100

\subsection{In-vitro release studies:}

In-vitro release studies for all the prepared patches were carried out for 12 hours. \% cumulative drug release after 12 hours was taken and compared for all the patches. F1 exhibited maximum drug release at the end of $12^{\text {th }}$ hour. Results are as shown in the table.

\subsection{Skin irritation study:}

Based on physicochemical evaluation and in-vitro release rate studies, F1 was selected for skin irritation test. Skin irritation test was performed on albino rabbits. No signs of erythema or redness were observed for 24 hours after the application of the patch.

\section{DISCUSSION:}

IR studies revealed that the drug and polymer were compatible with each other. Of all the batches prepared and evaluated, F1 showed promising results. It was concluded

\section{REFERENCES:}

1. Anon. Transdermal delivery systems - general drug release standards. Pharmacopoeial forum, 1980, 14(1), 108-110.

2. Berner B, John VA Pharmacokinetic characterization of Transdermal delivery systems. Jour. Clinical Pharmacokinetic, 1994, 26(2), 121-134.

3. Guy RH, Hadgaft J, Bucks DAW. Transdermal drug delivery and cutaneous metabolism, Xenobiotica, 1987, 17(3), 325352.

4. Gorus FK, Schuit FC, Intveld PA. Interaction of sulfonylureas with pancreatic beta cells-Astudy with gliburide.Diabetes, 1988, 37(8), 1090-1095.

5. www.drugbank.com.

6. Stroev EA, Belkina ZV. Effect of antidiabetic preparations on the processes of xenobiotic metabolism. Farmakol Toksikol, 1989,52(2), 74-77. that HPMC $5 \mathrm{cps}$ and ethyl cellulose are useful in formulating sustained release patches. Moreover, patches prepared from HPMC 5cps and EC (batch code = F1) exhibited better in-vitro drug release-time profile. Also, amongst the two plasticizers used alone and in various combinations, batch F9, F5 and F1 produced patches that exhibited high folding endurance and good manageable characteristics. Detailed investigations on in-vivo studies needs to be carried out and an in vivo- in vitro correlation need to be established to ensure the efficiency and bioavailability of the formulation.

\section{ACKNOWLEDGEMENTS:}

The authors are thankful to Ronak Life Care pvt Ltd, Patan, India, for providing us gift sample of Glipizide. The authors also wish to acknowledge with thanks to the management of Maharishi Arvind Institute of Pharmacy, Mansarovar, Jaipur, for providing the necessary support and facilities for our research project.

7. Deo MR, Sant VP, Parekh SR, khopade AJ andBankar UV. Proliposome based Transdermal delivery of levonorgestrel. Jour. Biomat. Appl. 1997, 12(1), 77-88.

8. Wiechers J. Use of chemical penetration enhancers in Transdermal drug delivery-possibilities and difficulties. Acta pharm, 1992,44(1), 123-127.

9. Sood A, Panchagnula R, Role of dissolution studies in controlled release drug delivery system. STP Pharma Sci. 1999,9(2), 157-168.

10. Brown MB and Jones SA. Hyaluronic acid: a unique topical vehicle for localized drug delivery of drugs to the skin, JEDV, 2000,19(3), 308-318.

11. Rao PR, Rmakrishna S, Diwan PV. Drug release kinetics from polymeric films containing propanolol hydrochloride for transdermal use, 2000,5(4), 465-472. 
12. Tripathi KD. Essential of Medical Pharmacology, $4^{\text {th }}$ ed. Jaypee Brothers Medical Publishers, New Delhi, 2004, 266274.

13. Devi VK, Saisivam S, Maria GR, Deepti PU. Design and evaluation of matrix diffusion controlled transdermal patches of Verapamil hydrochloride. Drug development and industrial pharmacy.2003, 29(5), 495-503.

14. Ali A, Rada S, Agarwal SP. Fabrication of diffusion cell for the determination of drug released from topical aerosol formulations. Indian drugs, 1997, 34(1), 715-717.

15. Qvist MH, Hoeck U, Kreilgaard B, Madsen F, Frokjaer S. Release of chemical permeation enhancers from drug-in- adhesive transdermal patches. Int. J. Pharm, 2002, 231(2), 253-263.

16. Al-Khamis K, Davis SS, Hadgraft J. Microviscosity and drug release from topical gel formulations. Pharm. Res. 1986, 3(2), 214-217.

17. Praveen M, Someswara Rao M, Kulkarni SV, Chetan Surpur Basavraj. Formulation and Evaluation of Tizanidine hydrochloride transdermal patches. IJDFR, 2011, 2(2), 298313.

18. JRD Gupta, R Irchhiaya, N Garud, Priyanka Tripathi. Formulation and evaluation of matrix type transdermal patches of glibenclamide. IJPSDR, 2009, 1(1), 46-50. 